\title{
Perspectives of Linguistically Sensitive Teaching as a Component of Inclusive Classrooms in Lithuanian General Education
}

\author{
Nemira Mačianskiené $\dot{1}^{1}$ Vilma Bijeikiené ${ }^{2}$
}

1 Vytautas Magnus University, Institute of Foreign Languages, K. Donelaičio g. 58, LT-44248 Kaunas, nemira.macianskiene@vdu.lt

2 Vytautas Magnus University, Institute of Foreign Languages, K. Donelaičio g. 58, LT-44248 Kaunas, vilma.bijeikiene@vdu.lt

Annotation. The study focuses on an inclusive learning environment for children whose L1 is different from the language of schooling suggesting linguistically sensitive teaching (LST) as the response to challenges of increasing multilingualism. It aims to identify prospective teachers' attitudes, beliefs, experiences, and viewpoints on how to achieve inclusive teaching using LST. Two qualitative frameworks - Reflection and Focus-Groups - were used to gather data on four dimensions: personal, instructional, institutional, and societal, two of which are presented here. The findings showed that LST can serve as a valuable component of inclusive general education.

Keywords: linguistically sensitive teaching, plurilingual approach, student teachers, attitudes, experiences, inclusive classroom.

\section{Introduction}

The dynamics of contemporary life of the 21st century has led to the exponential increase of digitalization in all spheres of our life, including intense real-life and virtual mobility, and the exchange of material and non-material culture. Consequently, both employment and educational areas have become multilingual and multicultural, and this potential provided by growing linguistic as well as cultural diversity caused the need not only to be harnessed but it also opened vast possibilities for its exploitation. Forced and voluntary migration of people heightened interest and research into the complexity and 
diversity of this phenomenon. Even such small countries as Lithuania have encountered issues caused by immigration or re-emigration and found themselves not properly prepared to face new challenges. The problem of creating an inclusive learning environment for all has been at the center of attention in this study, suggesting linguistically sensitive teaching (hereinafter, LST) as the response to a multitude of issues caused by the changing linguistic landscape.

The acuteness of this problem is vividly evidenced by the ongoing action research of a European policy reform project Linguistically sensitive teaching in all classrooms (LISTIAC). A survey conducted by the project research team among in-service teachers ( $n=150$ in Lithuania) has discovered that $64 \%$ of the participants have no experience in teaching students with the first (home) language other than the school language, 65\% have never participated in in-service training sessions about diversity in the classrooms, $82 \%$ have no experience in using any online resources for plurilingual or linguistically sensitive approaches (e.g. ECML).

The research problem. Lithuanian general education is not prepared for the increased internationalization of Lithuanian society and exposes an urgent need for the development of teacher competences to create an inclusive learning environment working in multilingual and multicultural classrooms. The present study was designed to determine the perspectives of linguistically sensitive teaching to ensure the creation of inclusive classrooms in Lithuanian general education schools.

The research aim was to identify the prospective teachers' attitudes and beliefs, their experience and viewpoints on how to create more inclusive teaching practices through the use of linguistically sensitive teaching in general education classrooms. To achieve the aim, the following objectives were set: 1 . To determine the prospective teachers' attitudes and beliefs with regard to LST; 2 . To learn about the prospective teachers' experience (awareness of) of the situations that prevent inclusion in general education classrooms due to a lack of implementation of LST; 3 . To identify the prospective teachers' educationally informed viewpoints on possible measures to be taken to implement LST in general education classrooms.

\section{Theoretical Background}

Communication with different social agents from across the world in various spheres of our life has enhanced the necessity to acquire multiple new competences, including language competences. The complex issues caused the appearance of new concepts; thus, a plethora of various terms emerged to describe approaches used in multilingual spaces to address the needs of people speaking different home (CEFR, 2018; Cummins, 2014;

\footnotetext{
1 http://listiac.org/
} 
2019; Ituiño Aguirre et al., 2021) or named (Otheguy et al., 2015; Garcia \& Otheguy, 2019) languages and representing different home cultures as well as people having communicative competences of a multitude of other languages (Llompart \& Birello, 2020).

Conceptualization of the term linguistically sensitive teaching, used in this research, calls for a brief analysis of other similar concepts used in the field, which sometimes may cause confusion. Multilingualism, the term adopted by the European Commission as well as the researchers all over the world, especially across the Atlantic Ocean (Cummins, 2018; Gazolla, 2016; Phillipson, 2018; Piller, 2012; Weber \& Horner, 2013) is "the knowledge of a number of languages, or the co-existence of different languages in a given society" (CEFR, 2001, 4). Meanwhile, plurilingualism, advocated by the Council of Europe, is viewed as a single, dynamic, interrelated and developing linguistic repertoire of an individual, which is uneven and changing and which allows plurilingual people to combine language competencies with their general competencies and various strategies in order to perform communicative tasks (CEFR, 2018, 31). Following the CEFR conceptualization of plurilingualism, Ituiño Aguirre et al describe LST as "a teaching approach that seeks to find an adequate, sensitive and inclusive answer to the question of the increasingly multilingual scenery in education" $(2021,49)$ including such aspects as multilingual environment, students' well-being and flexibility in the use of linguistic repertoires.

Analyzing the concepts of plurilingualism and translanguaging in search for commonalities and divergences, Garcia and Otheguy (2019) argue that they are epistemologically different and lead to different goals and approaches in language teaching. Translanguaging, as "the deployment of a speaker's full linguistic repertoire without regard for watchful adherence to the socially and politically defined boundaries of named (and usually national and state) languages" (Otheguy et al., 2015, 283; Vallejo \& Dooly, 2019), is juxtaposed with plurilingualism which takes into account the learner's first (home) languages. Although it is possible to disagree with the authors' idea that the focus of plurilingualism is the goal to acquire only partial competence in multiple languages and their statement that plurilingualism recognizes national languages of the "increasing number of black and brown refugees that enter the European Union" as only a temporary endeavor, however, these issues require further broader conceptualization.

Cummins and Persad (2014) use the term teaching through a multilingual lens, which embraces the philosophy and pedagogical practices with regard to promoting equitable opportunities for multilingual learners. Discussing the policy and teaching practice in Canada during the last 30 years, they acknowledge the achieved progress, but also admit a lack of coherent national policies articulated in this respect, which leads to the situation that learners' home languages are seen as irrelevant at school, even impeding the whole progress of a learner. They are also concerned with a lack of teacher pre- or in-service preparation to scaffold teaching in multilingual classes. One more term - linguistically responsive teaching - is used referring to providing assistance to students who speak other languages than English in the US mainstream classes where students learn academic 
content and skills through English and also develop their proficiency in English (Lucas, Villegas, \& Freedson, 2008). The term pluralistic approaches is used in the FREPA project, executed by numerous experts under the auspices of the European Centre for Modern Languages of the Council of Europe, to name didactic approaches employing teaching and learning activities that involve more than one variety of languages and cultures. Advocates of plurilingual education emphasize the importance of valuing the ability of all individuals to learn and use several languages, broaden their competences through plurilingual approaches the purpose of which is the creation of linguistic sensitivity and cultural understanding as the basis for democratic citizenship (Gilly, 2017).

For the purposes of this research, we will use the concept of linguistically sensitive teaching (hereinafter, LST), formulated within the LISTIAC project (Linguistically Sensitive Teaching in All Classrooms), which intends to realize the desired change in teacher cognition, the education, and professional development of teachers. LST calls for the teacher's ability to utilize and to encourage the use of pupils' plurilingual competence in the whole school (CEFR, 2018, 32).

Thus, the operationalized definition of linguistically sensitive teaching (LST) hereby will be due attention to all languages and their varieties in the classroom irrespective of the subject taught.

A lot of research has been performed, and a plethora of the EU recommendations issued on the importance of the development of learner language competences, but educational practice differs. Reflections of students witness a reality where insufficient student language competences lead to difficult situations in the classroom, insecurity and social exclusion, faced indifference, neglect, or inability of teachers and schools to properly deal with them. This problem requires due attention as our classrooms, similarly to the classrooms all over the world, are becoming more and more multilingual and multicultural.

\section{Methodology}

\section{Organization of research}

To closely serve the aim and objectives of this study, two qualitative methodology frameworks were chosen: the Reflection tool for $L S T$, which is currently designed by the LISTIAC project research team, and the Focus-group research model (Breen, 2006). In the LISTIAC project, reflection has been identified as a powerful measure to develop prospective teachers' professional competence as well as to help them build their professional identity. As seen by the LISTIAC research team, the Reflection tool for LST has to satisfy the needs of the student teachers and teacher practitioners to stimulate them to critically evaluate their beliefs, attitudes, and the ideological assumptions surrounding their teaching practices. Moreover, such a tool has to be easily accessible in terms of its 
terminological content as well as accessible for speakers of other than the main European languages. Although the Reflection tool for LST encompasses all stages of initial teacher education, the present study has adapted only two elements from the beginning stage, as they correspond to the aim and scope of the present study and to the participants' profile most. The participants were engaged in two tasks, namely, the discussion of the relevant policy documents to get equipped with the necessary knowledge, and the analysis of an LST related video episode to provoke their informed and critical reaction.

With regard to the first task, the participants were introduced to and analyzed the European language policy, the Common European Framework of Reference (2001), and Companion volume (2018). Secondly, they were given a video episode ${ }^{2}$ from ECML webpage, focusing on pedagogical resources and plurilingual approaches. The video episode features a ten-year-old Spanish-speaking student's experience on his first day in the class of Mathematics at a primary English medium school in the United States. The student Moises has good skills in Mathematics but cannot demonstrate them due to his limited competences of English. In his attempt to pass the Math exam, he receives no help or support from anybody at school: his Math teacher, the school administration, or his classmates.

The Focus-group research methodology was employed to "gain rich insight into attitudes and behaviors", to be "better equipped to understand and meaningfully explain" the communication phenomena with descriptive data (Allen, 2017). Investigation into students' and student teachers' attitudes, beliefs, experiences, and educationally informed viewpoints on possible measures to be taken to implement LST in general education classrooms was performed following the model presented by Breen (2006). A very detailed focus-group schedule was prepared which included the dates and time of group discussions, a list of opening, introductory, key, transitory, and ending questions, a statement to overcome ethical issues and data analysis procedure. Two researchers performed 12 focus group discussions via the MS Teams virtual learning platform, which is used for studies at the university. Discussions were then recorded and transcribed for thematic analysis performed after the discussion. The otter.ai transcription tool was employed to transfer data from audio/video to text.

The sample of research. A non-probability non-random purposeful sampling technique was used to select research participants expecting to obtain unique and rich information valuable for the study. The sample consisted of participants who have been exposed to similar experiences (acquaintance with the theory of LST and language teaching methodology, some pedagogical experience at a general education school).

Research participants. The research participants were 28 student teachers of their 1st and 2nd year of studies in major or minor pedagogical study programs and 35 3rd and 4th year first-cycle philology program students, who have just returned from their

2 https://maledive.ecml.at/Resourcesandlinks/Pedagogicalresources/tabid/3659/Default.aspx 
pedagogical practices performed in various general education schools. The participants were invited to participate in Focus-Groups (hereinafter, FGs) voluntarily, acquainted with the suggested timetable and 12 FGs were formed. The research participants were from Lithuania (42), China (11), and from Belarus, Italy, Kazakhstan, Spain, France, Syria, and Ukraine.

Data analysis. The analysis of the FG data was performed by each researcher separately through a three-step process: (1) axial coding was performed to identify certain themes/ subthemes and assign a reference number to sentences or groups of sentences on that theme/subtheme; (2) the frequency of codes was calculated within the group and among groups to identify which attitudes, beliefs, and experiences prevailed; (3) to maximize the reliability of the data, a reliability check was performed by inviting an independent researcher to view the transcripts and match the codes with the themes. The matching of codes with sentences appeared to be rather reliable with only $12 \%$ of mismatch.

Overcoming ethical issues. To overcome any ethical issues, the research participants were informed before and at the beginning of the research about the purpose of the research, its procedure, that the discussions will be recorded and confidentiality was assured: the participants were informed that their ideas are useful for the research and will not be disclosed to anyone outside the research team as the aim was to find out their attitudes and experiences as those of prospective teachers rather than particular individuals.

Research limitations. As the study used a non-probability non-random purposeful sample, it is impossible to draw statistically significant conclusions from the findings obtained; non-random selection of participants does not allow to draw inferences about a population on the whole. Additional qualitative or quantitative research methods are needed for further research.

\section{Research Findings and Discussion}

Research data obtained from the students and student teachers applying the Reflection tool for LST and a model of Focus-group research were distributed into 3 strands: Attitudes and Beliefs, Experience and Viewpoints on LST implementation measures. 4 dimensions were discerned in the first strand during the process of research analysis: personal (student), instructional (teacher), institutional (school) and societal; however, due to the scope of the article only the first two dimensions will be discussed here.

\section{Attitudes and Beliefs: Student dimension}

The student dimension encompasses the participants' reflections related to the feeling and actions of Moises, the main protagonist in the video episode, as well as the conduct of his class peers in relation to him. One of the major axes in this dimension is the participants' analysis of Moises' personality and his aptitude for Mathematics as significant 
potential for his success at school, as shown by the following descriptions ascribed to Moises by the participants of the study: Moises is a clever student that is competent in math; surpasses the whole class in mathematical knowledge; a really gifted student; his talent and hard work, etc. Furthermore, the participants accentuate the boy's strong motivation to study as well as his diligence and determination as demonstrated in the following examples: he was studying so hard for the test; he is hard-working and bright; Moises uses every spare minute to go through his Math textbook and manages to solve the math problem that his classmates could not; the video starts with a fragment showing Moises at home studying for a math test, confirming that this boy is motivated to achieve great results or Moises was striving for a better future, it especially shows in the part where he was preparing for an important test.

Another important axis in the participants' reflections is the juxtaposition of Moses' personality and efforts with his social surrounding both inside and outside the school. While reflecting on the clash between Moises' efforts and the teaching processes at school, the participants primarily single out the main hindrance in Moises' way, namely, his isolation resulting from the lack of competences in English, the language of schooling. This can be seen in the frequent use by the participants of such words as 'obstacle' 'barrier' or 'hurdle' in relation to Moises' linguistic situation and in the following quotes from the participants' reflections: Moises has difficulties communicating in his new school; due to his limited abilities to speak English, he feels like letters are falling from the page and nothing makes any sense; the young pupil meets a hurdle on his way which would be English; Moises is helpless [in the test]; his main obstacle is English - he cannot understand what the teacher explains or what is written in the textual tasks, etc. An accurate generalization of the tension between Moises' aptitude for Math and the linguistic barrier is presented in the following conclusion: He was studying so hard for the test and when he noticed the language barrier, the whole world collapsed on him.

The highly unfavorable linguistic circumstances, as pointed out by the participants, do not prevent Moises from displaying his active agency in pursuing his goal to take the exam in Mathematics, as set in the example: Moises tries not to give up - he uses the dictionary, seeks help from Spanish-speaking girl in his class and finally asks his teacher for a math test in Spanish. The boy's strong willingness to pursue help from the teacher is seen in other quotes as well: he comes up to the teacher and asks for help; he does attempt to seek help from his teacher; Moises' plead for help, etc.

With regard to his social surrounding outside the school, the participants make reference to Moises' immigrant family background marked by high social vulnerability due to his parents' low education and the absence of the competences of English among all family members. Despite a rather low social prospect, the participants note that the family is being very supportive to Moises. Thus, in view of such family profile, the participants describe Moises' situation as unfavorable not only because he lacks the fundamental tool for successful integration into the learning process, but also because he feels pressure to 
satisfy the expectations of the family, as illustrated by the following participants' words: exposed to high expectations; heavy burden on his shoulders; Moises is the hope of the non-English speaking family that has a hard time fitting in the U.S.A., etc. Other similar examples connect Moises' difficult situation with his sense of responsibility and accountability: Moises shows great responsibility to learn and help his family; feels emotionally pressured to get good grades as his family believes in him or does not flee and tries his best. Moises difficult situation with all his inner tensions and his struggle to overcome the linguistic and cultural obstacles are accurately contextualized in the following quote: $a$ non-native young boy trying to fit in the unfamiliar society.

Finally, the conduct of his class peers in relation to Moises has been broadly discussed by the participants in the focus-groups. All of the participants emphasized the unacceptable behavior of Moises' classmates in the episodes when Moise gave the correct answer to a Math problem and could not explain it to the class due to his lack of English and during the break in the school yard. Such words as 'teasing', 'bullying', 'mocking', 'laughing' and being 'mean' kept appearing in the participants' answers. To illustrate, the following examples can be considered: most of the children were mean to Moises; they laughed and bullied him being laughed off by the class; the boy is being mocked at by his classmates, some teasing and bullying are happening as well; was embarrassed by the fellow students as he was not being able to answer the teacher's questions in English, etc. In participants' further discussion, such behavior by the Moises classmates transcends their relation with Moises and is generalized by participants as a general culture- and language-based division in the school: one more aspect, that severely got stuck into my mind, is that there is a lot of bullying in this school $<\ldots>$ directed towards children, who speak only in Spanish or the pupils who speak English are bullying the other students one of them is even seen throwing trash at Moises and bullying him. While being fiercely critical of such behavior of Moises' classmates considering it totally unacceptable, the participants link the bullying in class to the teacher's role and the absence of her active intervention, as seen from the following example, when teacher and student had a malfunction of communication, boy's classmates started laughing and calling him names which did not raise Moises self-esteem. This brings the present analysis to the discussion of the instructional or teachers' dimension in the next section.

\section{Attitudes and Beliefs: Instructional (teacher) dimension}

The instructional dimension in the present study entails the participants' reflection on the teachers' role in the classroom as an active facilitator of the learning process, a committed bearer of the students' general well-being, and the apt mediator of difference, be it culture, language, or any other aspect of diversity. Building on the above assumptions and being equipped with a substantial understanding of LST and plurilingual approaches, the participants of the study reflect on the teacher's actions in the video with heavy criticism and disapproval of her actions for failing to perform the expected 
teacher's role. At the same time, however, the participants give her some credit for the intention to help Moises and present the actions she took in that attempt in the following examples: the teacher understands the problem and tries to ask for help [from the school principal]; seeks for ways of helping Moises with the school's principal; She tries to find a Spanish test that would help Moises; She wants to help Moises - asks for the test to be translated in Spanish, digs into school archives in an effort to find him bilingual material; Moises's Math teacher sees his potential and understands the problem, the teacher tried to find a solution but I can say that she didn't try enough, etc.

Most of this mild appraisal is complemented in the reflections with the conjunction 'but', which presupposes the ensuing statements of how the teacher's attempts to cater for Moises' and his classmates' needs have failed. While discussing the inadequacy in the teacher's actions, the participants mention the word 'limited' several times, for instance: Moises's Math teacher sees his potential and understands the problem, but she is limited by her availability to devote time after class and does not speak Spanish herself or the teacher, limited as she was, could have still left the dictionary, it has nothing that could help with the math test. In some cases, the participants explain this limitation as the teacher's straightforward adherence to the rules and authorities of the school, without taking any independent and commonsensical judgment. One of the episodes when the teacher blindly surrenders to the rules of the school is the episode when the teacher takes away Moises' bilingual dictionary as he is trying to read the text of the exam task: I was most shocked by the end, when Moises after solving non-textual tasks, and turning to the next page, took the dictionary into his hands to understand the tasks, but the teacher took the dictionary from him and said 'I'm sorry Moises, I have to take this from you, but if you have any questions, you can ask me'. In most of the participants' comments there feels a bitter resentment against such teacher's lack of empathy as she knows that Moises cannot give her questions in English and still offers it as an option.

When asked about the reasons of the teacher's failure, the participants highlight the lack of competence not only in dealing with a bilingual class but also in generally creating an inclusive atmosphere. First of all, most of the participants missed the teacher's effort to translanguage or to use the linguistic potential of the other students in the class who can speak Spanish: despite having several pupils in class, whose first language is Spanish, she does not encourage them to use their linguistic repertoire, neither she tries to translanguage herself. Moreover, the participants questioned the teacher's capacity of exploiting interactive methods in general, which could have been especially helpful in this linguistically sensitive situation: she did not encourage pupils to use different languages, although some of them knew more than one language quite well and children were not paired in groups, everyone worked individually.

The teacher's failure to create an inclusive classroom is evidenced by the participants' comments such as the teacher hasn't prevented Moises from 'being isolated' and from feeling 'uncomfortable' for linguistic reasons. As generalized in the following quotes: the kid wasn't given a chance to be a part of a community and the children are not supportive 
enough as well as the teacher, such a situation creates an utterly inappropriate environment for the development of non-English speakers. The participants also see the teacher as not creating favorable inclusive conditions through her demotivating attitude towards Moises' effort: by leaving Moises and saying that the test is not important the teacher demotivated him. Most of the participants accentuated that the failure of the teacher to attend to Moises' communicative needs is equally harmful to the intercultural development of all the class as summarized in the following example: Moreover, in my opinion, the good teacher is the one who notices everyone in his class and seeks that every child experiences success.

\section{Experience}

Another important research question focused on investigating the research participants' learning experiences with regard to the situations where, due to a lack of linguistically sensitive teaching, similar situations as the one discussed above occurred or might have occurred. The research participants were asked to reflect (A) if they had participated in any multilingual classrooms or schools during their practical training or while they were learning at school and (B) if they had observed similar situations, and how they were solved.

Out of 63 research participants, $71.4 \%$ (45) related to multilingual classrooms either during their school years (12), during their studies at the university in their home country (16), or abroad (Erasmus mobility (4) or during their practical training (9). There were a few cases (4) when students recalled their friends' or relatives' experiences in similar situations. $76 \%$ of participants (34) recalled various issues related to communication difficulties, social exclusion, verbal abuse, lack of teacher attention, and unsecure learning environment of students with limited schooling language proficiency or lack of it.

Most of the research participants admitted observing a lack of proper language sensitive teaching, which caused problematic situations outside Lithuania. One respondent recalled the childhood experiences as a primary school learner of an immigrant family in Iceland: Sometimes I even cried when I didn't know how to answer the teacher's question. $\langle\ldots>$ A child surrounded by strangers finds it especially difficult to learn from their mistakes when there is a fear of being ridiculed.

Some students had negative experiences from their Erasmus mobility programs in Spain and in Italy, where the language of schooling was in the state language and the students' basic language skills did not help them to understand teacher's explanations in university level courses; teachers were not responsive and refused to use any other language to make the content understandable.

Multilingual classrooms, according to a respondent from Italy, are a norm in the country with "a foreign language population around 5.3 million or $9 \%$ of the overall population", so various language related issues occur, resulting in instances of social exclusion, and sometimes are not dealt with due to a lack of LST:

I had a couple of classmates in my elementary who were originally from South America, namely Ecuador and Peru, and were not proficient in the Italian language. 
They truly struggled understanding the teacher's instructions, as well as participating actively both in scholarly and social settings. Overall, this has hindered their education because they could not keep up with the rest of the Italian students, and eventually some of them did not complete their formal education (FG11).

A student from China referred to psychological difficulties she experienced at school due to different dialects spoken all over the country. Because of her parents' work they had to change schools four times before she graduated from a primary school:

Every time ... when I go from a familiar school to a new school, everything was strange to me. I have to meet the new teachers and classmates. However, the most difficult is dialect. In China, different places have different dialects, and people speak the same language but have different accents. So, I have to learn different dialects in order to adapt to my new school life. Every time ..., I always think about that ... If I didn't go to school so many times, maybe I would become a different person from now. Whenever I enter a new school, I will be laughed at because of my accent, so my personality becomes more and more introverted (FG3).

Although in Lithuania monolingual classrooms still prevail, the situation has been rapidly changing over the last two decades. However, society (including students and teachers) still lacks intercultural competences and skills, tolerance and understanding of what it means to find oneself in situations where your home language is unappreciated and where your efforts to speak the language of schooling are undervalued.

This problem is still relevant to this day in Lithuania. My first school was a Russian speaking gymnasium and after the 8 grade I went to [X school] and it was really difficult for me to communicate with teachers and students because my knowledge of the Lithuanian language was poor and it was difficult even to understand what teachers are saying to me. I was bullied for that I couldn't speak Lithuanian without any mistakes and even teachers would giggle about it. It was difficult not only for me but nearly for every Russian or Ukrainian speaking student to learn something or just to be a part of the society, and some teachers didn't do anything to help the student (FG10).

Some problems occur due to teachers' lack of language competences, e.g. the Russian (the language of schooling) or Lithuanian (state language) language competences working in a multilingual school.

During my time in a multilingual school, teachers were absolutely not prepared to face students that weren't proficient in neither Russian or Lithuanian; some teachers didn't know Lithuanian well too. Thus, students from purely Lithuanian backgrounds or foreigners faced difficulties in Mathematics class, or Physics, Chemistry, as they were taught using old Russian textbooks. In general, there was a predominance of an unofficial language due to the staff (FG1).

Another participant recalled a situation in a local village school where he heard when a teacher dropped an inappropriate comment about Roma children that they were straightforwardly evil - it was so depressing (FG4) rather than setting an example of tolerance and respect. 
Nowadays migration is not a phenomenon and situations like Moises' becomes an everyday challenge in a regular school. In Lithuania there are lots of families that emigrate and come back after a while with children who do not speak Lithuanian. There are also many families that immigrate from other countries and their children probably have not even heard Lithuanian language before. I know that there are lots of teachers who try to help foreign students as much as possible. Sadly, I have seen some teachers who did not even try to help their students to adapt, to share their knowledge (FG6).

So it is evident that students have encountered situations where lack of appropriate teacher's behavior in difficult situations caused by multilingualism not only violated students' linguistic human rights (Skutnabb-Kangas, 2018; Phillipson, 2018) but also led to unsolved issues that may have difficult consequences on students' health, motivation, and well-being. On the other hand, students' linguistic repertoire which could have been used as a valuable learning resource was seen as a hindrance rather than an asset and was not even addressed.

\section{Viewpoints on LST Implementation}

Lucas, Villegas and Freedson (2008), Harvard Graduate School of Education researchers, suggest three types of pedagogical expertise for linguistically responsive teaching to happen: familiarity with students' linguistic and academic backgrounds, understanding of the language demands that go along with learning tasks and skills to deploy appropriate scaffolding, i.e. assistance with explanations, mediation, etc.

The research respondents suggested a variety of ways how the problems caused due to a lack of proper linguistically sensitive teaching implemented at school could have been solved or how to avoid such situations from occurring in the future. Some of the suggestions refer to language, others - to teacher's behavior, whereas the rest - to attitudes, beliefs and values:

- Teachers should introduce newcomers to the class and show respect to the language(s) and culture(s) of the newcomer (FG2);

- Students of the same nationality should be introduced in such schools (they will feel less lonely and scared) (FG9);

- Schools should have textbooks and other material and learning resources in student languages (FG5);

- Teachers should be multilingual or invite multilingual assistants (schools should cooperate with universities and invite volunteers (teachers and students) to assist with various languages of the newcomers (FG12);

Teachers should be trained to use pluralist methods as part of their education. This can be achieved through courses and workshops. Also, it would be ideal to have teachers speaking several languages, if not tutors could be used as well. Teaching materials supporting pluralistic approaches should be widespread and easily accessible to teachers as well (FG7). 
- Teachers should be over tolerant and open-minded, have basic knowledge of culture and traditions of their students (FG5) p. 101;

- Various events should be organized: foreign students could teach their classmates about their culture/ language, acting like teachers. In any case, the goal is to broaden the students' view on languages and cultures, so that there would be less bullying and more acceptance and interest (FG3).

There were some unexpected findings, such as the situation with Immersion was explained as a political act of the US against immigrants: It is evident that the US works on decreasing the number of immigrants, especially from southern countries. This is the reason why teachers are told not to help Spanish speaking children (FG10).

Another unexpected finding came from a decision-driven young respondent and was related to a lack of finances as an explanation of why situations such as the one with Moises occur. A practical solution was offered: to ensure additional help to immigrant children and organize afterschool classes for them, the school could ask for additional funds from local government or organize fundraises (FG8).

The suggested solutions allow to assume that the prospective teachers have acquired knowledge and formed positive attitudes towards the implementation of LST in general education schools and exhibited enough creativity, empathy and tolerance towards the discussed issue; therefore, success in their ability to implement LST in practice can be predicted based on the evidence provided above.

\section{Conclusions}

Although monolingual classrooms still prevail in Lithuanian general education schools, multilingual and multicultural classrooms have emerged, and schools have to be prepared to ensure the well-being and secure environment for all students. The emerging multilingual and multicultural classrooms are simultaneously expanding the required repertoire of teacher competences so that they could satisfy the learning and inclusion needs of students from diverse backgrounds. While the types of inclusion could be varied, one of the possibilities to create more inclusive classrooms in Lithuanian general education is through the application of linguistically sensitive teaching. LST is undoubtedly a very novel concept in Lithuanian education. Moreover, its application is still thoroughly examined as an innovation in the European countries with much longer and richer tradition of linguistic and cultural diversity in education, such as Belgium, Portugal, Spain, France, or Finland (cf. LISTIAC project).

In light of the above assumptions, the present study aimed at discovering the possibilities of the implementation of LST in Lithuanian general education by analyzing three relevant components in the development of prospective teachers' competences: their attitudes towards the application of LST, their personal experience of learning in 
multilingual settings and their possible projections as to how they envision LST in the schools of the future. A focus-group method was chosen to generate students' reflections, preceded by the analysis of the necessary policy documents, and activated through a thought-provoking and engaging video episode on the lack of LST practices. The video episode allowed us to elicit a range of participants' insights into the research problem, namely, how challenging the teaching of multilingual children can become, what destructive impact on the children's learning achievements can be made by inadequacies in the teacher's actions and decisions and what significant role inclusiveness plays in creating the overall well-being of the class.

The participants admitted having a lot of experience in learning or participating in multilingual classrooms and shared their experiences. A number of problems caused by a lack of schooling language competence were mentioned: insecurity, lack of confidence, learning demotivation, teacher's inability to help students, bullying, or abuse on the part of peers. The respondents also provided a number of solutions on how to apply LST in the classroom. It is possible to conclude that the theoretical knowledge gained during studies and practical, reflective activities raise students' awareness about the implementation of plurilingual approaches in the classroom and equip them with the necessary skills on how to plan for the implementation of LST in their future teaching practices.

\section{References}

Allen, M. (Ed.). (2017). The SAGE encyclopedia of communication research methods. Canada: Sage Publishing. doi: http://dx.doi.org/10.4135/9781483381411.n208

Breen, R. L. (2006). A practical guide to focus-group research. Journal of Geography in Higher Education, 30(3), 463-475. Routledge. doi:10.1080/03098260600927575

Council of Europe. (2018, February) Common European framework of reference for languages:

Learning, teaching, assessment. Companion volume with new descriptors. https://rm.coe.int/ cefr-companion-volume-with-new-descriptors-2018/1680787989

Council of EU. (2016). Conclusions on multilingualism and the development of language competences. EU: Council of European Union. https://www.consilium.europa.eu/uedocs/ cms data/docs/pressdata/en/educ/142692.pdf

Cummins, J. (2019). Should schools undermine or sustain multilingualism? An analysis of theory, research, and pedagogical practice. Sustainable Multilingualism, 15(1), 1-26. https:// doi.org/10.2478/sm-2019-0011

Cummins, J. \& Persad, R. (2014). Teaching through a multilingual lens: The evolution of EAL policy and practice in Canada, Education Matters, 2(1), 3-40.

ECML. Pedagogical resources. https://maledive.ecml.at/Resourcesandlinks/Pedagogicalresources/ tabid/3659/Default.aspx 
European Commission. (2015). Language learning and teaching in multilingual classroom. Luxembourg: Publication Office of the European Union. http://ec.europa.eu/languages/policy/ learning-languages/multilingual-classrooms en.htm

FREPA. (2012). Framework of reference for pluralistic approaches to languages and cultures. Competences and resources. https://www.ecml.at/Portals/1/documents/ECML-resources/ CARAP-EN.pdf?ver=2018-03-20-120658-443

García, O., \& Otheguy, R. (2020). Plurilingualism and translanguaging: commonalities and divergences. International Journal of Bilingual Education and Bilingualism, 23(1), 1735. doi:10.1080/13670050.2019.1598932

Gazolla, M. (2016). Multilingual communication for whom? Language policy and fairness in the European Union. European Union Politics, 17(4), 546-569. https://doi. org/10.1177/1465116516657672

Gilly, D. (2017). Plurilingualism and language sensitive teaching - recent curricular developments in teacher education.

BIMM: UCTE Styria by the Federal Ministry for Education. https://www.ecml. at/Portals/1/documents/events/2017-colloquium/Presentation Dagmar updated. pdf?ver=2018-01-16-160306-053

Ituiño Aguirre, L., van der Worp, K., Saragueta, E., Galdos, O., \& Gaspar, A. (2021). Linguistically sensitive teaching in a multilingual context: perceptions of pre-service teachers of the Basque autonomous community. Sustainable Multilingualism, 18, 45-70.

Llompart, J. \& Birello, M. (2020). Migrant and non-migrant origin pre-service teachers' beliefs about multilingualism and teaching in multilingual classrooms: convergences and divergences. Sustainable Multilingualism, 17, 102-123. https://doi.org/10.2478/sm-2020-0015

Lucas, T., Villegas, A.M., \& Freedson, M. (2008). Linguistically responsive teacher education: Preparing classroom teachers to teach English language learners. Journal of Teacher Education, 59(4), 361-373. https://doi.org/10.1177/0022487108322110

Otheguy, R., García, O. \& Reid, W. (2014). Clarifying translanguaging and deconstructing named languages: A perspective from linguistics. Applied Linguistics Review, 6(3), 281-307. doi: https://doi.org/10.1080/15348458.2017.1329657

Piller, I. (2012). Multilingualism and social exclusion. In M. Martin-Jones, A. Blackledge, A. Creese (Eds.), The Routledge Handbook of Multilingualism (pp. 281-296). Routledge.

Phillipson, R. (2018). Language challenges in regional and global integration. Sustainable Multilingualism, 12, 14-35. doi:https://doi.org/10.2478/sm-2018-0001

Skutnabb-Kangas, T. (2018). Linguistic diversity, language rights and language ecology, Sustainable Multilingualism, 13, 14-58. doi:https://doi.org/10.2478/sm-2018-0011

Weber, J. J. \& Horner, K. (2013). Introducing multilingualism: A social approach. Language, Identity \& Education, 12(3), 203-206. doi:10.1080/15348458.2013.813301

Vallejo, C. \& Dooly, M. (2019). Plurilingualism and translanguaging: emergent approaches and shared concerns. Introduction to the special issue. International Journal of Bilingual Education and Bilingualism, 23(1), 1-16. doi:10.1080/13670050.2019.1600469 


\title{
Kalbai jautraus mokymo perspektyvos kuriant įtraukią aplinką Lietuvos bendrojo lavinimo mokykloje
}

\author{
Nemira Mačianskiené ${ }^{1}$, Vilma Bijeikiené ${ }^{2}$ \\ Vytauto Didžiojo universitetas, Užsienio kalbų institutas, K. Donelaičio g. 58, 44248 Kaunas, \\ nemira.macianskiene@vdu.lt \\ 2 Vytauto Didžiojo universitetas, Užsienio kalbų institutas, K. Donelaičio g. 58, 44248 Kaunas, \\ vilma.bijeikiene@vdu.lt
}

\section{Santrauka}

Šiuolaikinio gyvenimo dinamika, skatinanti priverstinę ir savanorišką migraciją pasaulyje ir reikalaujanti tyrèjų dèmesio jos sukeltų problemų kompleksiškumo ir ịvairovės analizei, neaplenkẻ ir švietimo institucijų. Švietimo erdvei tampant vis labiau daugiakalbei ir daugiakultūrei, didejja skaičius vaikų, kurių pirmoji arba namų kalba nėra mokyklos kalba. Šio tyrimo centre ittraukiančiojo ugdymo komponentų paieška besikeičiančios lingvistinès erdvès kontekste, pateikiant kalbai jautrų mokymą kaip vieną iš galimų šios problemos sprendimo perspektyvų. Tyrimo tikslas - nustatyti būsimų mokytojų požiūrị ir ịsitikinimus, patirtị ir gebejimą rasti kalbai jautraus mokymo igyvendinimo klaseje sprendimus, kuriant ịtraukią aplinką bendrojo lavinimo mokykloje. Duomenys tyrimo analizei rinkti pasitelkiant du kokybinès metodologijos instrumentus - kalbai jautriam mokymui skirtą refleksijos įrankị (sukurtą LISTIAC projekte) ir tikslinès grupès (Focus-group) modelį. Šie instrumentai leido surinkti duomenis keturiais pjūviais - asmeniniu (mokinio ir studento/ studento-mokytojo), didaktiniu (mokytojo), institucijos (mokyklos) ir visuomeniniu. Šiame straipsnyje pristatomi tik pirmieji du problemos pjūviai. Tyrimo rezultatai leidžia daryti išvadas, kad kalbai jautrus mokymas gali būti pasitelkiamas kaip vertingas ịtraukiojo ugdymo igyvendinimo bendrojo lavinimo mokyklose komponentas, sprendžiant daugiakalbès kompetencijos trūkumo problemas.

Esminiai žodžiai: kalbai jautrus mokymas, daugiakalbyste, mokytojai, mokiniai, nuostatos, patirtys, įtraukaus ugdymo klase. 